\title{
OPENNESS AND PRODUCTIVITY: THE ROLE OF IMPORTS, FDI AND INTERNATIONAL TELECOMMUNICATIONS*
}

\section{YANLING WANG**}

Previous research has shown that trade and FDI are beneficial to countries' economic development. This paper builds on the literature, and analyzes the effects on total factor productivity (TFP) through three channels of openness - imports, inward FDI and international call traffic (ICT) for a set of developing countries in Asia and Latin America and the Caribbean (LAC). Using data from the period of 1980 to 2000, I find that imports, FDI and international call traffic all significantly promote TFP growth in developing countries, and that human capital enhances the effects of imports on TFP.

JEL classification: F1, F2

Keywords: TFP, imports, FDI, international call traffic

\section{INTRODUCTION}

There is a general consensus that, overall, countries gain from openness through trade and foreign direct investment (FDI). Indeed, mutual gains from trade are the main driving forces for countries to engage in regional or multilateral free trade negotiations. Dr. Jagdish Bhagwati, a leading trade economist, has long been an advocate for multilateral trade negotiations to reduce the barriers to trade and FDI. ${ }^{1}$ In 2000 , the World Bank commissioned a study that examined the effects on countries' economies of regional trade agreements, and concluded that countries can obtain dynamic gains from more open trade relations through increased efficiencies. ${ }^{2}$ Recent literature supports the finding

\footnotetext{
* I benefited greatly from discussions with Maurice Schiff and comments from conference participants at the Canadian Economics Association annual meetings in Toronto, and the Chinese Economists Society annual meetings in Nanning. Comments from two anonymous referees were very helpful and constructive in improving the paper. Financial support from the Social Sciences and Humanities Research Council is acknowledged.

** School of International Affairs, Carleton University, 1125 Colonel By Drive, Ottawa, ON K1S 5B6, Canada, and School of Economics, Henan University. E-mail: Yanling_Wang@carleton.ca.

1. Dr. Bhagwati is the author of an op-ed published in the New York Times on July 24, 2011, titled "The Wrong Way to Free Trade", in which he suggests the Obama administration make efforts to restart the long-stalled Doha round of trade negotiations, pointing out the potential benefits to the United States of the conclusion of the Doha round and the immeasurable harm which could result from its failure.

2. The World Bank (2000) points out that openness to trade generates three types of dynamic gains. The first results from competition: firms are induced to cut prices and increase sales, benefiting consumers by reducing monopolistic distortion. The second arises as market enlargement allows firms to fully exploit economies of scale. The third source is possible reductions in internal inefficiencies that firms are induced to make. Dynamic gains have also been found in a number of studies. For example, Roberts and Tybout (1996) find that openness to trade reduces price-cost margins, an indicator of competitive pressure in the industry.
} 
that trade not only opens up opportunities for countries to specialize in certain goods to better reap the benefits of scale economies, but also promotes international technology spillovers, because countries get access to the technology embedded in imported goods that they do not produce (Grossman and Helpman, 1991).

FDI as an openness channel to promote technology spillovers has been recognized and examined in previous literature. Foreign direct investment originates primarily from multinational enterprises (MNEs) in industrialized countries, which have more advanced technology, greater product variety and better management skills (Markusen, 1995; Caves, 2007). Thus, countries have enacted regulations designed to attract FDI, hoping to benefit from their positive spillover effects. ${ }^{3}$ Inward FDI is perceived to benefit the host economy not only through job creation, but also through technology spillovers to local firms, along with other gains (Gorg and Greenaway, 2004).

This paper builds on the previous literature, but adds a third channel of openness, namely, international telecommunications through call traffic. Technology spillovers through international call traffic (ICT) are straightforward, but have not been as well analyzed in the literature, presumably due to data limitations. Unlike knowledge that spills over through trade and FDI, international technology spillovers from ICT take a different route, i.e., they do not require a specific form of conduit. Through international call traffic, knowledge flows between the two ends of a phone line. In that sense, technology spillovers through ICT could be referred to as moving through an "un-embedded channel", while technology spillovers through trade and FDI could be referred to as moving through an "embedded channel". Through embedded channels, the direction of the movements of goods embodies technological content from the producing country, and FDI of the technological content of the originating country. Knowledge transfers through conversations are indifferent between the directions of the called placed, i.e., incoming or outgoing international call traffic. For example, when a professional A in country $c$ talks with a professional B in country $N$, professional A could learn of the relevant technology

3. The United Nations' 2001 World Investment Report summarizes the national policy developments regarding FDI from 1991 to 2000 (p6., Box Table I.1.1). The table shows the number of countries that introduced policy changes regarding FDI, the number of regulatory changes, and whether the changes represent liberation/promotion or regulations/restrictions. The overwhelming majority of the regulatory changes are more favorable to inward FDI. For instance, 147 out of the total 150 regulatory changes in 2000 promote FDI, while in 1991, 80 out of the total 82 promote FDI. 
developed in country $N$ through professional $\mathrm{B}$, and this learning process is invariant to who placed the call.

Adding the channel of international call traffic, this paper studies the benefits on total factor productivity (TFP) for a sample of relatively open developing countries from openness in terms of imports, inward FDI and ICT. The joint effects of openness from three channels and the choice of a set of relatively open developing countries make some contributions to the existing literature. First, for the three channels of imports, inward FDI and ICT are the least likely to suffer omitted variable bias when we examine the effects of each channel on TFP. Second, when measuring developing countries' openness, we limit their partners to only 20 developed OECD countries in the North. These countries account for the overwhelming majority of world research and development $(\mathrm{R} \& \mathrm{D})$ expenditures, and are the technological frontiers. ${ }^{4}$ Thus, openness to them provides the necessary basis for access to advanced technologies. Third, the study chooses a sample of developing countries in Asia and Latin America and the Caribbean (LAC) that have been actively integrating into the global economy by enacting open trade policies and signing regional trade agreements. The sample thus provides a good basis for measuring the marginal effects of openness. The period from 1981 to 2000 witnessed increased trade flows and record annual amounts of FDI flows to Asia and LAC. For instance, in Asia, China and India have both implemented open economic policies, and both have experienced rapid growth in trade and inward FDI. ${ }^{5,6}$ In LAC, geographical proximity to North America and Europe makes these countries among the first developing countries to integrate into the world economy, through free trade agreements (FTAs). For instance, Mexico became a member of the North America

\footnotetext{
4. In $1995,95 \%$ of the world's R\&D expenditures were in industrial countries (calculated by the author from the World Bank database).

5. In 1978, the Chinese government, under the leadership of Deng Xiaoping, embarked on a series of economic reforms designed to integrate China into the world economy. It gradually liberalized its trade regime and enacted regulations to attract foreign investment, and also privatized many state-owned enterprises. This took place over four major periods, each of which had a different emphasis. The first period was from 1978 to 1987, when the major reforms in the Chinese trade system consisted of assigning trading rights and quotas to major trading firms. The second period was from 1988 to 1992, when the major reform was the elimination of export subsidies and implementation of a dual-track exchange system. The third period was from 1993 to 2001, when the reform focused on eliminating the dual-track exchange system. The last period was from 2001 onward, the so-called post-WTO period. The Chinese government has taken bold steps to honor its WTO commitments through reforms of its trading system by amending its major trade regulations. Since 1978, China's economy has experienced an average annual growth rate of about $9 \%$.

6. The Indian government relaxed controls on foreign trade and investment in the early 1990s and the Indian economy has posted an average growth rate of $6 \%$ since 1990 . In addition, the poverty rate has been reduced by about 10 percentage points.
} 
FTA (NAFTA) in 1994. FDI inflows to Asia and to LAC increased dramatically during the period, and account for a large share of gross fixed capital formation, especially in LAC. ${ }^{7}$

With data from 1981 to 2000, I find that: i) imports, FDI and ICT all generate significant positive effects on TFP; ii) the effects of imports on TFP are the most significant, followed by those of ICT and then by those of FDI; iii) the positive effects of trade, FDI and ICT, to a certain degree, are all facilitated by developing countries' absorptive capacity, though this is the strongest for imports; and iv) the results are robust across different sample sizes.

The remainder of the paper is constructed as follows. Section 2 reviews the related literature, Section 3 sets forth a brief analytical framework, Section 4 describes the data, Section 5 presents the empirical results, and Section 6 concludes the paper.

\section{THE LiterATURE}

There are rich empirical studies regarding the effects on TFP of imports, inward FDI and ICT, with research on trade and FDI leading the way. In an influential study, Frankel and Romer (1999) showed that trade results in economic growth. Their finding implies that the more open an economy, the faster its growth rate, ceteris paribus. In a series of studies from a related but different perspective, Dollar and Kraay showed that trade benefits the poor by helping to alleviate poverty, and that countries with solid institutions can take better advantage of the benefits associated with openness (Dollar and Kraay, 2003; 2004). The positive effects of openness in trade led Noguer and Siscart to title their paper, "Trade Raises Income: A Precise and Robust Result" (Noguer and Siscart, 2005). Furthermore, the literature has shown that trade with developed OECD countries in the North significantly increases TFP for their trading partners, not only in the developed world (Coe and Helpman, 1995; Coe et al., 2008), but also in the developing world (Coe et al., 1997; Engelbrecht, 1997; Schiff and Wang, 2006).

7. Although the absolute values of FDI inflows to LAC are smaller than those to Asia, presumably because of the smaller size of the LAC economy, FDI inflows accounted for a much larger portion of fixed capital formation in LAC than in Asia. For instance, although Asian developing countries attracted record yearly FDI inflows, the ratio of FDI inflows to gross fixed capital formation in Asia ranged from 3 to $10 \%$ in the $1990 \mathrm{~s}$, but 5 to $25 \%$ in LAC (World Investment Report, 2001). 
Regarding the effects of inward FDI, most empirical studies have shown that inward FDI is beneficial to the recipient countries. For instance, at the aggregate level, Borensztein et al. (1998) found that FDI promotes economic growth for a large sample of developing countries, and Balasubramanyam et al. (1999) reached similar results, although Van Pottelsberghe and Lichtenberg (2001) showed that only countries with overseas FDI in R\&D-intensive countries benefit from overseas FDI, not from inward FDI. ${ }^{8}$

Although international call traffic is a viable way to spread international technology, studies on this phenomenon are few and far between. In an earlier study, Wong (2004) showed that both trade and ICT are important channels for TFP growth in a large sample of developing countries, but he limited ICT only to incoming call traffic, rather than the sum of incoming and outgoing call traffic as used in the paper. So far, no empirical studies have jointly examined the three channels of trade, FDI and ICT in international technology diffusion, although two of the three channels have been examined together by some. For instance, the combined effects from trade and FDI were examined in Cuadros et al. (2004), Gao (2004) and Schiff and Wang (2008). Seck (2011) went one step further by also including the quality of institutions in developing countries, finding that imports appear to be more conducive to R\&D spillover and that developing countries that enjoy greater benefits tend to exhibit a larger stock of human capital, more openness to trade and foreign activities (FDI), and stronger institutions. This paper adds to the literature by studying the effects of TFP from three channels of imports, inward FDI and ICT for a sample of countries that are relatively open among developing countries.

8. Although not directly related to this study, micro-level studies have identified three main channels through which FDI spillovers take place: horizontal intra-industry economic linkage, and backward and forward vertical inter-industry linkages. Intra-industry linkages refer to the economic relationships between domestic- and foreign-controlled firms within the same industry, including learning (spillover) effects from foreign affiliates to domestic-owned firms and competition for market share among them. Backward inter-industry linkage is the economic relationships of an industry with its upstream industries through purchasing intermediate inputs from them, while forward inter-industry linkage consists of the economic relationships of an industry with its downstream industries through selling products to them. Horizontal intra-industry effects of FDI are jointly determined by positive spillover effects and negative competition effects, and are thus country-specific in terms of the empirical results. For example, several studies find that FDI generates overall positive intra-industry effects on the productivity of domestic firms-Haddad and Harrison (1993) found this for Morocco, Chuang and Lin (1999) for Taiwan, and Branstetter (2005) and Keller and Yeaple (2009) for the U.S., while others documented negative effects of FDI-Aitken and Harrigan (1999) did so for Venezuela. The inter-industry effects of FDI are positive overall-Javorcik (2004) found substantial FDI spillover effects for Lithuanian-owned firms through backward linkages, and similar findings can be found in Blalock and Gertler (2008) for Indonesia, Jordaan (2008) for Mexico and Wang (2010) for Canada, to name a few. 


\section{THE ANALYTICAL FRAMEWORK}

Here, we follow traditional wisdom by assuming that for developing country $c$, its total factor productivity at year $t, T F P_{c t}$, is determined mainly by the following factors:

$$
T F P_{c t}=F\left(\text { Openness }_{c t}^{N}\right) G\left(X_{c t}\right)
$$

where Openness ${ }_{c t}^{N}$ captures the openness of developing country $c$ to the developed countries in the North, and $X$ is a vector including all other factors affecting a country's TFP. Here, we consider only openness to the developed countries in the North, mainly because developed countries are perceived to be technological leaders, and thus for developing countries, economic linkages with them are generally considered to be a good choice. Openness to the North is proxied by three measures of a country's imports volume, inward FDI stock, and its bilateral (the sum of incoming and outgoing) ICT respectively. ${ }^{9}$

Openness measured by imports is defined as the ratio of developing country $c$ 's imports of machinery and transportation equipment from country $N$, Imports ${ }_{c}^{N}$, to its gross domestic product (GDP). Imports of machinery and transportation equipment are used rather than total imports from the North because the former provides a better indication of the producing country's technology level, as argued in Coe et al. (1997). Openness measured by FDI is defined as the ratio of the inward FDI stock from country $N, F D I_{C}^{N}$, to country $c$ 's GDP. ${ }^{10}$ Openness measured through ICT is defined as the ratio of bilateral telephone call traffic (in minutes - the sum of incoming and outgoing call traffic) between countries $c$ and $N), I T C_{C}^{N}$, over country $c$ 's population. ${ }^{11}$

With the above definitions and the assumption that each channel exerts independent effects on TFP, Equation (1) can be rewritten as:

9. Another related set of literature specifies a different estimation equation, lead by Coe and Helpman (1995) and followed by others. In those studies, they estimated a TFP equation with the independent variable of a trade-related technology index, which is built as a composite knowledge index of a country's trading partners' R\&D stock, weighted by that country's import shares from these trading partners. That approach, although adapted by others, cannot explicitly differentiate the driving forces in TFP growth to determine whether it is the increase in trading partners' knowledge stock or increases in import shares - which is a measure of openness.

10. FDI stocks do not fluctuate as much as FDI flows, and thus empirical analyses are less likely to be negatively affected by some short-term fluctuations.

11. I prefer to use only international calling for business purposes, but data on bilateral calling do not differentiate between business and non-business purposes. 


$$
T F P_{c t}=\left(\frac{\operatorname{Imports}_{c t}^{N}}{G D P_{c t}}\right)^{\alpha}\left(\frac{F D I_{c t}^{N}}{G D P_{c t}}\right)^{\beta}\left(\frac{I C T_{c t}^{N}}{P o p_{c t}}\right)^{\gamma} G\left(X_{c t}\right)
$$

Taking logs of Equation (2) leads to the following:

$$
\begin{aligned}
\ln T F P_{c t}= & \alpha \ln \left(\frac{\text { Imports }_{c t}^{N}}{G D P_{c t}}\right)+\beta \ln \left(\frac{F D I_{c t}^{N}}{G D P_{c t}}\right) \\
& +\gamma \ln \left(\frac{I C T_{c t}^{N}}{P o p_{c t}}\right)+\ln G\left(X_{c t}\right)
\end{aligned}
$$

We assume that $G\left(X_{c t}\right)=\exp \left(H C_{c t}^{\sigma}\right)$, where HC is a country's human capital, proxied by total years of schooling over its population aged 25 and above. A developing country's technology (such as spending on R\&D) is not included, due to data unavailability. For simplicity, I denote openness to the North through imports, FDI and ICT respectively as $I M P_{-} G D P \equiv\left(\right.$ Imports $\left._{c t}^{N} / G D P_{c t}\right), F D I_{-} G D P \equiv\left(F D I_{c t}^{N} / G D P_{c t}\right)$, and $I C T_{-} P O P \equiv\left(I C T_{c t}^{N} / P_{o p}\right)$. With these new notations, Equation (3) can be rewritten as:

$$
\begin{aligned}
\ln T F P_{c t}= & \alpha+\beta^{\operatorname{Im} \text { port }} \ln I M P_{-} G D P_{c t}+\beta^{F D I} \ln F D I \_G D P_{c t} \\
& +\beta^{I T C} \ln I C T_{-} P O P_{c t}+\beta^{H R} H R_{c t}
\end{aligned}
$$

The panel nature of the data allows further freedom to control for other factors that could affect a country's TFP growth. To control for heterogeneous country effects, such as government policies, shocks, and other country-specific features that might also be correlated with a country's TFP, I add country-specific intercepts to Equation (4). To control for exogenous world events affecting all countries, I add year dummies. In light of discussions concerning the amount of time developing countries need to be able to utilize the technologies embedded in imports and FDI (Coe et al., 1997; Schiff and Wang, 2008), I use one-period lagged terms in the regression. Due to the technological gap between the North and developing countries, some researchers have argued that developing countries must have a certain level of absorptive capacity for the more advanced technology to be better adapted and then put into productive use (Borensztein et al., 1998; 
Wang, 2007). In what follows, I will test how developing countries' absorptive capacity affects the impacts generated by imports, FDI and ICT, by adding the product of human capital to the three main variables. The regression equation thus becomes:

$$
\begin{aligned}
\ln T F P_{c t}= & \alpha+\beta^{\operatorname{Im} p o r t} L^{1} \ln I M P_{-} G D P_{c t} \\
& +\beta^{F D I} L^{1} \ln F D I_{-} G D P_{c t}+\beta^{I T C} L^{1} \ln I C T_{-} P O P_{c t} \\
& +\beta^{H R} H R_{c t}+\beta^{I M P_{-} H R} L^{1} \ln I M P_{-} G D P_{c t} * H R_{c t} \\
& +\beta^{F D I}{ }^{H R} L^{1} \ln F D I_{-} G D P_{c t} * H R_{c t} \\
& +\beta^{I T C}{ }_{-}^{H R} L^{1} \ln I C T_{-} P O P_{c t} * H R_{c t} \\
& +\sum_{c=2} \gamma_{c} \operatorname{Coun}_{c}+\sum_{t=2} \phi_{t} Y_{e a r_{t}}+\varepsilon_{c t}
\end{aligned}
$$

where Coun and Year indicate country and year dummies respectively.

\section{DATA SOURCES}

Our sample consists of 13 developing countries in Asia and 17 developing countries in LAC, for a total of 30 countries. ${ }^{12}$ The sample covers the period of 1981 to 2000 when developing countries were very actively integrating into the world economy. Twenty developed industrial OECD countries in the North are considered partners for imports, FDI and ICT. ${ }^{13}$ I will briefly document the data sources and explain how I constructed each index.

The log of TFP index is calculated as the log difference between valueadded and the primary factor use of labor and capital, weighted by their income shares. Writing it out leads to $\ln T F P=\ln Y-\alpha \ln L-(1-\alpha) \ln K$,

12. The 13 countries and territories in Asia are: Bangladesh, China, Hong Kong (China), Indonesia, India, Korea, Sri Lanka, Macao (China), Malaysia, Pakistan, the Philippines, Singapore, and Thailand. The 17 countries in LAC are: Argentina, Bolivia, Brazil, Chile, Colombia, Costa Rica, Ecuador, El Salvador, Guatemala, Honduras, Mexico, Nicaragua, Panama, Peru, Paraguay, Uruguay, and Venezuela.

13. The 20 developed OECD countries are: Australia, Austria, Belgium, Canada, Denmark, Finland, France, Germany, Iceland, Ireland, Italy, Japan, Luxembourg, Netherlands, New Zealand, Norway, Portugal, Spain, Switzerland, the United Kingdom, and the United States. We limit OECD countries to these 20 industrialized ones (excluding developing countries) to highlight the more advanced technologies in the partner country. 
where $Y, L$ and $K$ stand for value added, labor and capital stocks respectively, and $a$ is a country-specific labor share, defined as the mean of the ratio of the wage-bill ratio divided by value added during the sample period. The use of time-invariant, country-specific labor share combined with a country dummy in the econometric analysis will make the empirical results invariant to the unit of measurement of capital (in units or in thousands, for instance). Capital stocks are derived from the fixed capital formation series using the perpetual inventory method with a $5 \%$ depreciation rate. Value-added, fixed capital formation, labor and wages are all taken from the United Nations National Accounts. Value-added and gross fixed capital formation series are reported in current U.S. dollars, and both are deflated by the U.S. GDP deflator $(1990=100)$ before being used to construct the TFP index.

Bilateral FDI stocks from each of the 20 industrialized OECD countries to developing countries are taken from the OECD's FDI database. Only 17 of the 30 developing countries are included in that database, but they are the major FDI recipients in the developing world. ${ }^{14}$

Bilateral imports of machinery and transportation equipment are taken from the World Integrated Trading System (WITS) database, with certain data not available for some country pairs.

Data on bilateral international telecommunications (call traffic) in minutes start in 1983, the earliest year for which this data are available. For 1983-1995, the data are taken from TeleGeography's International Telecommunication database; and for 1996-2000, they are from TeleGeography's International Traffic database.

Data on GDP and population are taken from the World Development Indicators. The average total years of schooling among the population aged 25 and above are taken from the Barro-Lee dataset, annualized here. Macao (China) is not included in the Barro-Lee dataset, but is in the sample. Here, I assume that Macao's educational attainment is the same as Hong Kong's, given that the two regions are very similar in terms of development stages, culture and political systems.

Table 1 reports the mean of the four dependent variables for the 30 developing countries during the sample period. First, comparing FDI

14. They are: Argentina, Brazil, Chile, China, Colombia, Costa Rica, Hong Kong (China), India, Indonesia, South Korea, Mexico, Malaysia, Panama, the Philippines, Singapore, Thailand, and Venezuela. Eight are in Asia and nine are in LAC. 
with imports of machinery and transportation equipment, it clearly indicates that the majority of the developing countries attracted relatively more FDI than the money spent on imported equipment: 15 of the 17 countries with both trade and FDI data have a larger ratio of FDI-to-GDP than that of imports-to-GDP. Second, the accumulated FDI stock-to-GDP ratio is still very small for almost all developing countries, except for Costa Rica, Hong Kong and Panama.

\section{EMPIRICAL RESULTS}

\subsection{The endogeneity problem}

Time-series regressions presented here may be subject to possible endogeneity problems. Taking imports as an example, countries with higher productivities for reasons other than trade may have more imports. To test for endogeneity, we follow the technique developed by Wooldridge (2002), which involves two steps. The first step is to regress the variable in question on all other independent variables to obtein its residuals and the second step is to include the residual term in the full regression, including the variable in question itself. ${ }^{15}$ If the residual term turns out to be statistically significant, then the variable in question is endogenous. Following that technique, the endogeneity tests are performed for $L^{1} \ln I M P_{-} G D P, L^{1} \ln F D I_{-} G D P$ and $L^{1} \ln I C T_{-} P O P$ respectively. The coefficient on the residual term for $L^{1} \ln \bar{I} M P_{-} G D P$ is not significant, leading to the rejection of endogeneity for $L^{1} \ln I M P_{-} G D P$. A similar result is obtained for $L^{1} \ln F D I_{-} G D P$. However, the coefficient of the residual term from $L^{1} \ln I C T_{-}^{-} P O P$ is statistically significant. Thus, I perform endogeneity tests by using the two-period lagged term, $L^{2} \ln I C T_{-} P O P$, and the three-period lagged term, $L^{3} \ln I C T_{-} P O P$. The test results indicate that the residual for the three-period lagged term, $L^{3} \ln I C T_{-} P O P$ is not statistically significant. Accordingly, the empirical analysis is derived from $L^{1} \ln I M P_{-} G D P, L^{1} \ln F D I_{-} G D P$ and $L^{3} \ln I C T_{-} P O P$.

15. There is a tendency for imports, FDI and ICT to move together, causing a multi-collinearity problem. In the dataset, the correlation coefficient between $L^{1} \ln I M P P_{-} G D P$ and $L^{1} \ln F D I$ GDP is 0.46 , between $L^{1} \ln I M P_{-} G D P$ and $L^{3} \ln I C T_{-} P O P$ it is 0.58 , and between $L^{\overline{1}} \ln F D I_{-} G D P$ and $L^{3} \ln I C T+P O P$ it is 0.38 . These low correlation coefficients signal that the multi-collinearity problem won't be a major concern. On a safety test, assuming that the multi-collinearity among the variables should be explicitly taken care of, I run the endogeneity test again for each variable by removing the other two channels. That is, for instance, when I test the endogeneity for $L^{1} \ln I M P P_{-} G D P$, I exclude $L^{1} \ln F D I_{-} G D P$ and $L^{3} \ln I C T+P O P$ from the list of independent variables. The test results are similar. 
Table 1. Sample mean of the main variables by country (1981-2000)

\begin{tabular}{lcccc}
\hline Country & $\begin{array}{c}\text { FDI/GDP } \\
\text { (\%) }\end{array}$ & $\begin{array}{c}\text { IMP (imports of } \\
\text { MT) } / \text { GDP (\%) }\end{array}$ & $\begin{array}{c}\text { ICT/POP. } \\
\text { (in minutes) }\end{array}$ & $\begin{array}{c}\text { Average years } \\
\text { of schooling }\end{array}$ \\
\hline Argentina & 0.57 & 0.07 & 68.01 & 7.61 \\
Bangladesh & -- & 0.08 & 8.75 & 2.16 \\
Bolivia & -- & 0.32 & 85.36 & 4.77 \\
Brazil & 0.75 & 0.07 & 25.85 & 3.79 \\
Chile & 1.21 & 0.26 & 134.21 & 6.97 \\
China & 0.17 & 0.25 & 5.27 & 4.95 \\
Colombia & 0.80 & 0.18 & 149.82 & 4.46 \\
Costa Rica & 6.36 & 0.36 & 418.49 & 5.53 \\
Ecuador & -- & 0.31 & 215.08 & 5.96 \\
El Salvador & -- & 0.27 & 821.70 & 3.79 \\
Guatemala & -- & 0.26 & 391.15 & 2.67 \\
Honduras & -- & 0.51 & 558.15 & 3.64 \\
Hong Kong & 2.35 & 0.75 & 1557.51 & 8.40 \\
India & 0.10 & 0.08 & 5.28 & 3.75 \\
Indonesia & 1.67 & 0.30 & 9.09 & 3.78 \\
Korea & 0.28 & 0.31 & 177.81 & 9.11 \\
Macao & -- & 0.20 & 441.34 & 8.40 \\
Malaysia & 1.48 & 1.08 & 105.52 & 6.16 \\
Mexico & 0.76 & 0.48 & 438.47 & 5.61 \\
Nicaragua & -- & 0.57 & 326.00 & 3.67 \\
Pakistan & -- & 0.21 & 37.80 & 2.17 \\
Panama & 47.58 & 0.31 & 606.91 & 7.09 \\
Paraguay & -- & 0.23 & 48.41 & 5.41 \\
Peru & -- & 0.14 & 86.20 & 6.27 \\
Philippines & 0.99 & 0.36 & 102.76 & 6.99 \\
Singapore & 3.75 & 1.83 & 1496.64 & 6.05 \\
Sri Lanka & -- & 0.29 & 82.00 & 5.47 \\
Thailand & 0.86 & 0.44 & 41.69 & 5.27 \\
Uruguay & -- & 0.10 & 140.17 & 6.70 \\
Venezuela & 0.73 & 0.33 & 136.41 & 5.23 \\
All Countries & $\mathbf{4 . 1 4}$ & $\mathbf{0 . 3 7}$ & $\mathbf{2 9 0 . 7 2}$ & $\mathbf{5 . 3 9}$ \\
MT: machinery and transportation equipment. ICT: international call traffic, described in Section 3. \\
\hline
\end{tabular}




\subsection{Main results}

Table 2 presents the baseline regression results by using $L^{1} \ln I M P \_G D P$, $L^{1} \ln F D I \_G D P$ and $L^{3} \ln I C T$ POP, without the interaction terms with human capital. Columns (i) to (iii) present the effects on TFP generated by each of the three channels, columns (iv) to (vi) show the effects of two of them, and column (vii) shows the effects of combining them all. Note that the number of observations varies across each column, depending on the variables included. This is especially true with FDI. I discuss the results in turn.

First, imports, FDI and ICT all significantly increase TFP in the sample of developing countries. This result is consistent with previous findings in the literature, as reported in Borensztein et al. (1998), Wong (2004), Schiff and Wang (2008) and Seck (2011).

Second, imports generate the largest impact on TFP, followed by ICT and then FDI. A 100\% increase in imports, FDI and ICT leads to an increase in TFP by $4.3 \%, 1 \%$ and $2.5 \%$ respectively. An F-test indicates that the effects of imports on TFP are significantly larger than those of FDI and ICT, while the effects of FDI and ICT are not statistically different. The greater effects from trade as compared to other channels are in line with the findings in Schiff and Wang (2008), Wong (2004) and Seck (2011). The results here lend additional support to previous findings that imports are an important channel for promoting technology spillover across countries (Coe and Helpman, 2005; Wang, 2007). While FDI promotes technology spillovers, it also stimulates and increases competition in the host countries. The overall effects of FDI are the net effects from the positive spillover effects and the often negative competition effects, which are smaller than the effect of imports. Similarly, as a channel for international technology spillover, ICT allows developing countries to get access to partner countries' technology through conversation with no negative competition effects attached, and thus the results are slightly higher than those for FDI, though they are not statistically significant.

Turning to the effects on TFP of human capital, we find that human capital has significant independent effects on increasing developing countries' TFP. The impact ranges from 0.028 (column i) to 0.071 (column vii), all significant at the $1 \%$ level. 


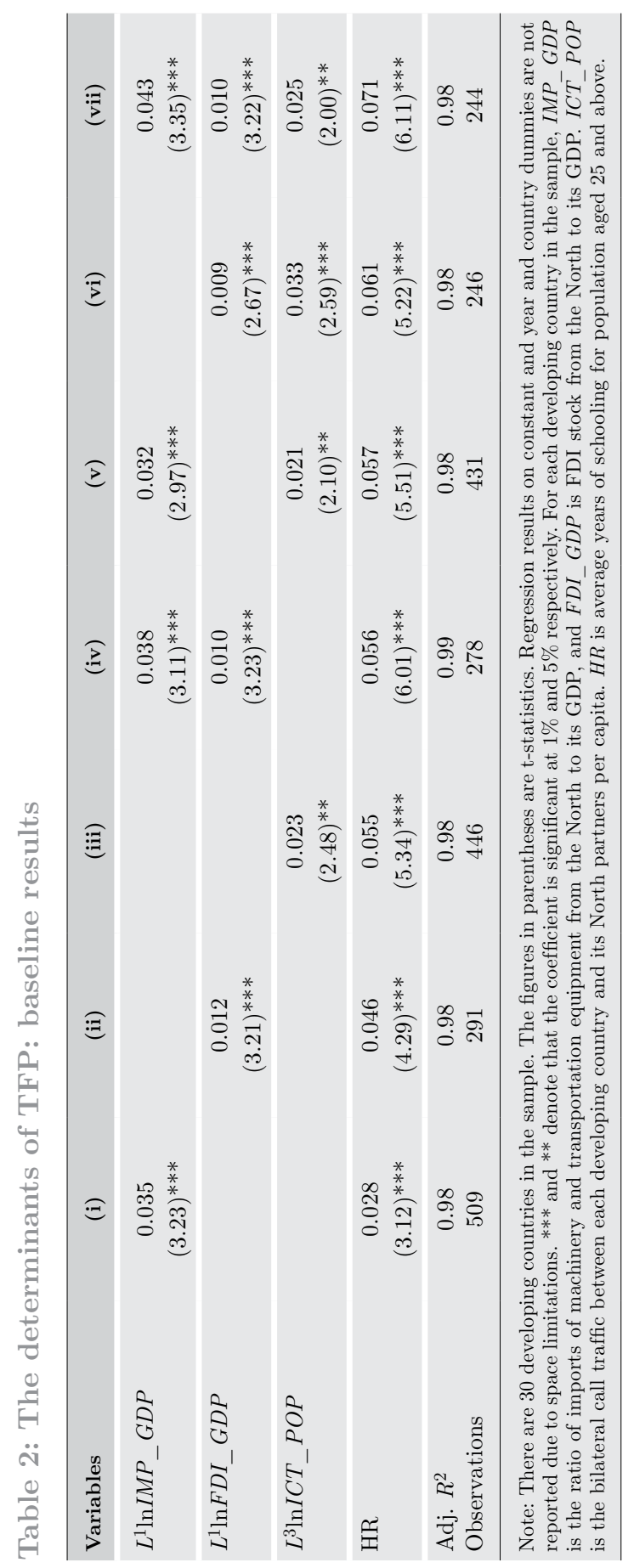




\subsection{Results with interaction terms}

Table 3 adds the interaction terms between human capital and all of the three main independent variables to see how a country's absorptive capacity affects the impacts of imports, FDI and ICT. First, the results here clearly indicate that developing countries' absorptive capacity is important in facilitating the effects of imports, FDI and ICT. With imports as the only channel for technology diffusion, the elasticity of TFP with respect to the import ratio is $0.026\left(-0.102+0.023^{*} 5.582\right)$, significantly different from zero, with 5.582 the mean of years of schooling for the regression equation in column i). ${ }^{16}$ The results suggest that there is a threshold of human capital (average years of schooling) above which imports generate significant effects on TFP. The threshold is 4.435 $(=0.102 / 0.023)$. We find similar results with respect to FDI (column ii), although the coefficient of the interaction term is not significant (but it is positive). The overall elasticity of TFP with respect to FDI is $0.013\left(=-0.005+0.003^{*} 6.087\right)$, where 6.087 is the average years of schooling for that regression. For countries to be able to benefit from the spillover effects of FDI, the minimum level of schooling years is $1.67(-0.005 / 0.003)$ years. In the sample, the average number of years of schooling is 5.582 for all countries (with a minimum of 2.16 years for Bangladesh and a maximum of 9.11 years for Korea), and 6.087 for the subsample with FDI data. That implies that all countries in the sample are able to benefit from inward FDI. As for ICT, it generates independent positive effects, which are increased significantly by a country's human capital (column iii). The overall elasticity of TFP with respect to the ICT ratio is $0.038\left(=0.010+0.005^{*} 5.641\right)$, where 5.641 is the average years of schooling in that regression, higher than its independent results in column (iii) in Table 2.

Second, the positive effects of human capital for FDI and ICT are not as robust as those for imports. When two of the channels are included in one regression, the effects of FDI are significantly enhanced by human capital, although this is not always the case with ICT. With all three channels included in the regression, the only significant interaction term is with imports, implying that a certain level of human capital is important in facilitating the productive use of technology embedded in imports, a result found in Wang (2007). 
The results here generate some important policy implications. For developing countries, opening up the economy by engaging in trade and attracting more foreign direct investment is indeed beneficial to their productivity growth. Increased economic integration leads to increased international communications through call traffic, which in turn facilitates international technology spillovers. Increased human capital through education has dual effects: it directly increases productivity growth and indirectly facilitates international technology spillover through imports. To a certain degree, these results are not new, but they shed additional light on efforts by many countries to engage in unilateral trade liberalization and regional and multilateral trade negotiations: Countries stand to gain from unilateral, bilateral or multilateral reductions on barriers to facilitate flows of goods and capital. Developing countries in LAC are generally more open than their counterparts on other continents, and it is in their interest to continue their efforts to integrate with the world economy through unilateral trade liberalization, and/or through regional and multilateral trade negotiations.

\subsection{Some sensitivity analyses: different sample size}

The unbalanced dataset offers a good opportunity to check the robustness of the results, especially regarding imports and ICT, given the lack of availability of FDI data for many countries. When I compare the results of imports, ICT and FDI in columns (i) to (iii) in tables 2 and 3 , the number of countries decreases from 30 for imports and ICT to 17 countries once FDI is also included. The countries with FDI data are generally more open: the mean of $I M P \_G D P$ is $0.439 \%$, compared to $0.365 \%$ for the whole sample; and the mean of $I C T_{-} P O P$ is 322.34 minutes, compared to 290.73 minutes for the whole sample. In what follows, I limit the sample size to the 17 countries that have data on imports, FDI and ICT, and re-estimate the regressions in tables 2 and 3 to see how the results change. The results are reported in tables 4 and 5 respectively.

A comparison of the results in tables 2 and 4 clearly indicates that the elasticity of TFP with respect to imports and to the ICT ratio is consistent regardless of the sample size. With the interaction terms, Table 5 reports an elasticity of TFP with respect to the import ratio that is $0.042(=-0.102+0.023 * 6.26$, where 6.26 is the mean years of schooling for the reduced sample size) in column (i), significantly 


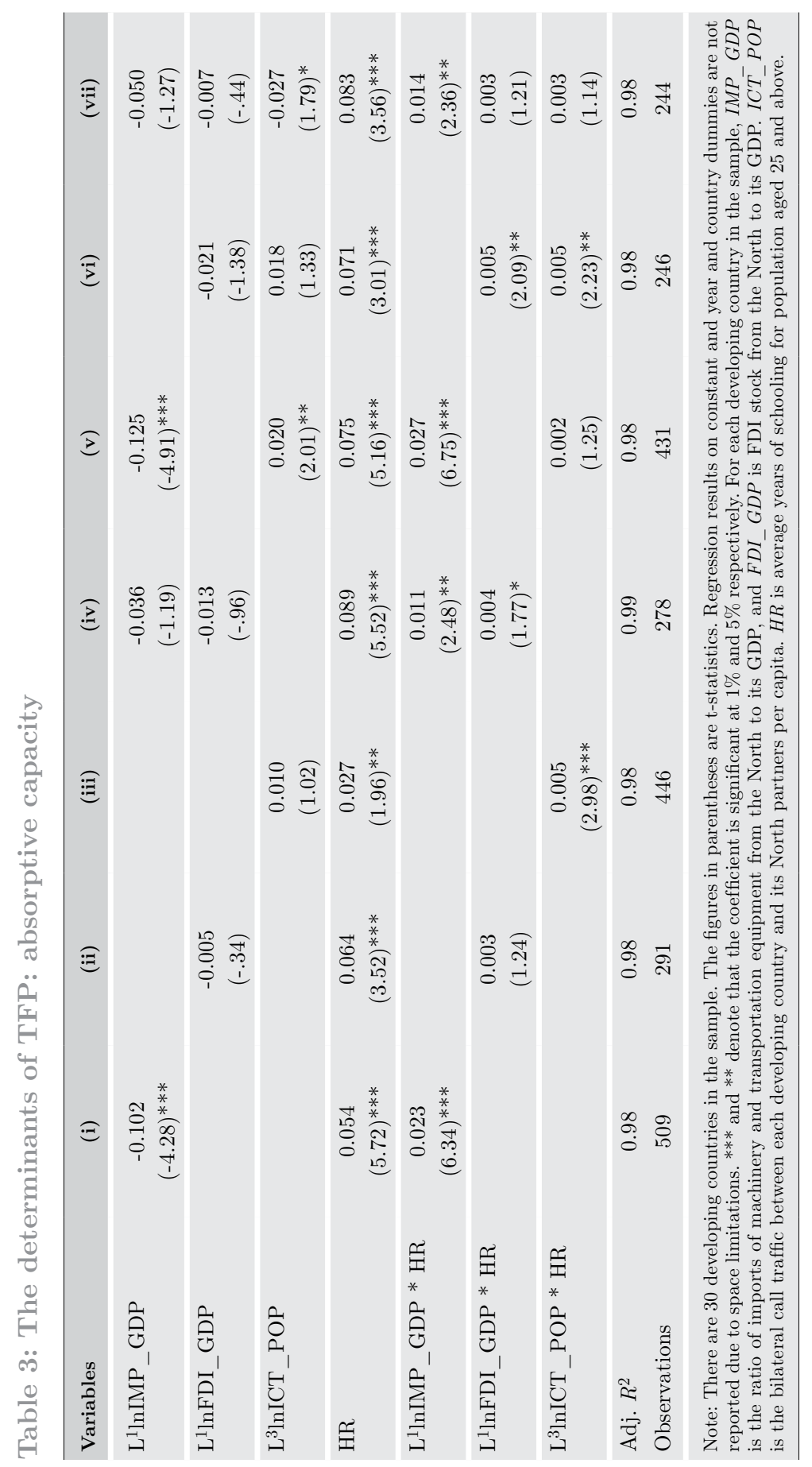




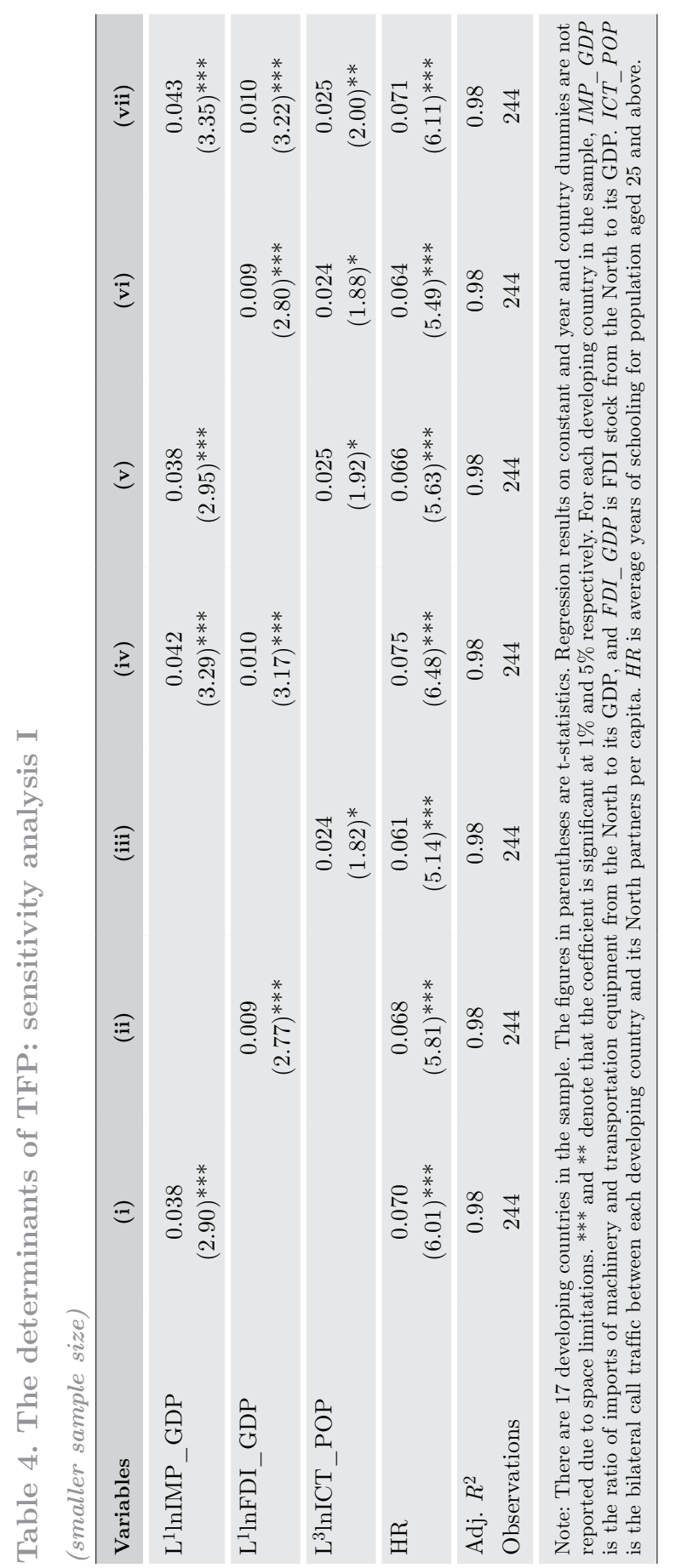




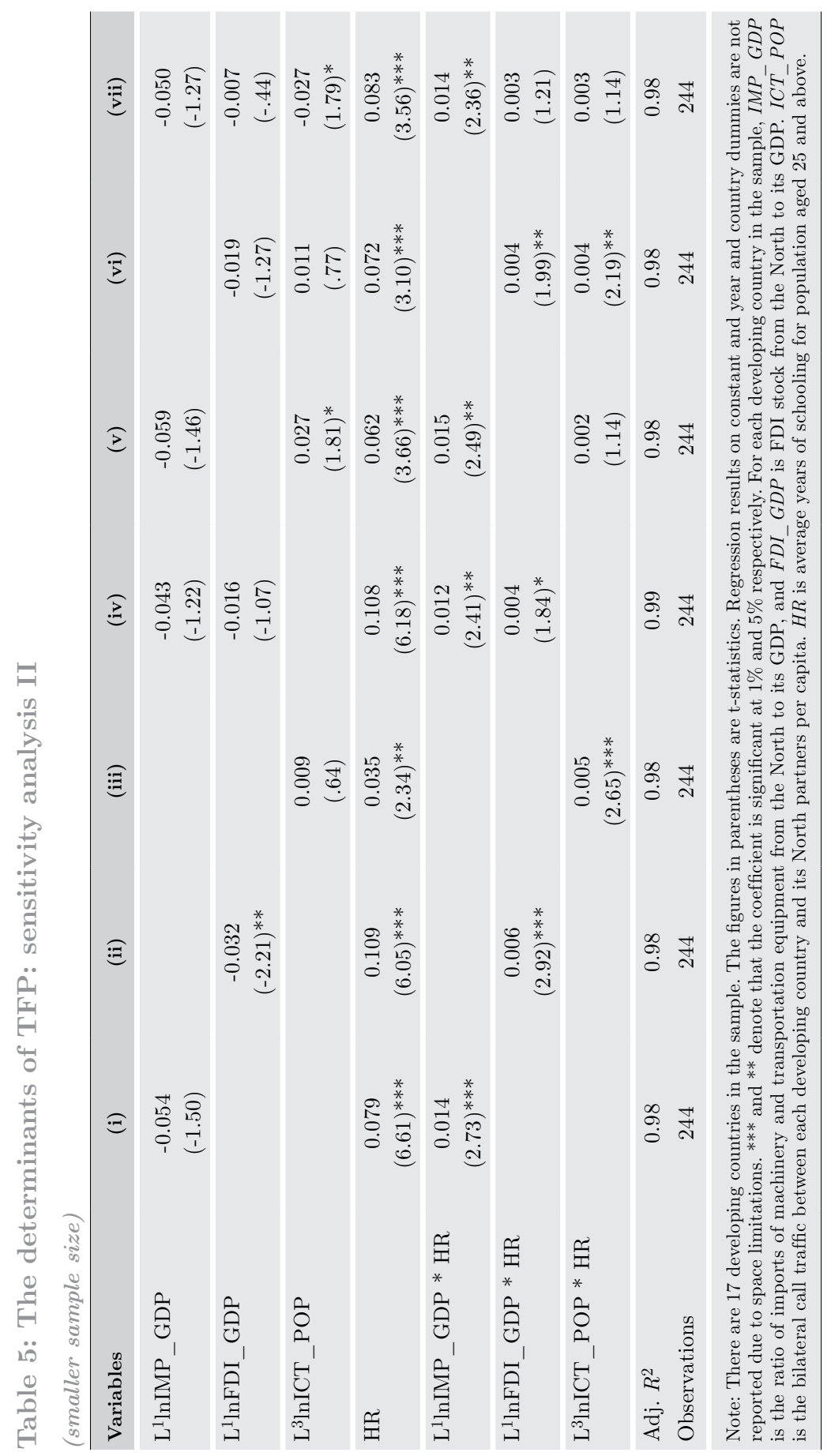


different from zero. That is higher than that reported in column (i) in Table 3. The increase in elasticity is mainly due to the increased mean of years of schooling in the smaller sample. Column (iii) in Table 5 reveals an elasticity of TFP with respect to the ICT ratio of $0.040\left(=0.009+0.005^{*} 6.26\right)$, close to the 0.038 reported in column (iii) in Table 3 . The results in Table 5 reinforce the findings for the whole sample.

\section{Concluding Remarks}

This paper analyzes the effects of openness with the industrialized OECD countries in the North on TFP in developing countries in Asia and Latin America and the Caribbean (LAC). The openness of developing countries to the North is measured by the ratio of imports to their GDP, ratio of inward FDI stock to their GDP, and the ratio of international call traffic (ICT) to their population. With 20 industrialized OECD countries as partners, for the 30 developing countries in Asia and LAC during the period of 1981 to 2000, the paper reaches the following conclusions: First, imports, inward FDI and ICT all significantly promote technology diffusion to increase developing countries' TFP. Second, the effects on TFP are the largest from imports, followed by ICT and FDI, although the latter two are not statistically significant from each other. Third, human capital exerts independent positive effects on TFP, and also significantly increases the effects of imports on TFP. The results are robust across different sample sizes. The findings here lend support to the efforts made by many developing countries to engage in unilateral trade liberalization and regional and multilateral trade agreements to enhance the benefits of openness on productivity. 


\section{REFERENCES}

Aitken, B.J. and A.E. Harrison (1999), "Do domestic firms benefit from direct foreign investment? Evidence from Venezuela," American Economic Review Vol. 89, No.3: 605-18.

Balasubramanyam, V.N., M. Salisu, and D. Sapsford (1999), "Foreign direct investment as an engine of growth," Journal of International Trade $\mathcal{G}$ Economic Development Vol. 8, No. 1:27-40.

Blalock, G. and P. Gertler (2008), "Welfare gains from foreign direct investment through technology transfer to local suppliers," Journal of International Economics Vol. 74: 401-21.

Borensztein E., J. De Gregorio, and J-W Lee (1998), "How does foreign direct investment affect economic growth?" Journal of International Economics Vol. 45: 115-135.

Branstetter, L. (2005), "Is foreign direct investment a channel of knowledge spillovers? Evidence from Japan's FDI in the United States," Journal of International Economics Vol. 68: 325-44.

Caves, R.E. (2007), Multinational enterprise and economic analysis, $2^{\text {nd }}$ edition, Boston: Cambridge University Press.

Chuang, Y-C and C-M Lin (1999), "Foreign direct investment, R\&D and spillover efficiency: Evidence from Taiwan's manufacturing firms," Journal of Development Studies Vol. 3, No. 4: 117-137.

Coe, D.T. and E. Helpman (1995), "International R\&D spillovers," European Economic Review Vol. 39: 859-87.

Coe, D.T., E. Helpman, and A.W. Hoffmaister (1997), "North-south R\&D spillovers," Economic Journal Vol. 107: 134-149.

Coe, D.T., E. Helpman, and A.W. Hoffmaister (2008), "International R\&D spillovers and institutions," IMF Working Paper, WP/08/104.

Cuadros, A., V. Orts, and M. Alguacil (2004), "Openness and growth: Re-examining foreign direct investment, trade and output linkages in Latin America," Journal of Development Studies Vol. 40, No. 4: 67-192.

Dollar, D. and A. Kraay (2003), "Institutions, trade and growth," Journal of Monetary Economics Vol. 50, No. 1: 133-62.

Dollar, D. and A. Kraay (2004), "Trade, growth, and poverty," Economic Journal, Vol. 114, No. 493: F22-49.

Engelbrecht, H-J. (1997), "Human capital and international knowledge spillovers in TFP growth of a sample of developing countries: An explanation of alternative approaches," Applied Economics Vol. 34: 831-41.

Frankel, J.A. and D. Romer (1999), "Does trade cause growth?" American Economic Review Vol. 89, No. 3: 379-99.

Gao, T. (2004), "FDI, openness and income," Journal of International Trade 8 Economic Growth Vol. 13, No. 3: 305-23. 
Gorg, H. and D. Greenaway (2004), "Much ado about nothing? Do domestic firms really benefit from foreign direct investment?" World Bank Research Observer 19: 171-97.

Grossman, M.G. and E. Helpman (1991), Innovation and growth in the global economy, Cambridge: The MIT Press.

Haddad, M. and A. Harrison (1993), "Are there positive spillovers from direct foreign investment? Evidence from panel data for Morocco," Journal of Development Economics Vol. 42: 51-74.

Javorcik, B.S. (2004), "Does foreign direct investment increase the productivity of domestic firms? In search of spillovers through backward linkages," American Economic Review Vol. 94: 605-27.

Jordaan, J.A. (2008), "Intra- and inter-industry externalities from foreign direct investment in the Mexican manufacturing sector: New evidence from Mexican regions," World Development, Vol. 36: 2838-54.

Keller,W. and S.R. Yeaple (2009), "Multinational enterprises, international trade and productivity growth: Firm-level rvidence from the United States," Review of Economics and Statistics, Vol. 91, No. 4: 821-31.

Markusen, J. (1995), "Incorporating the multinational enterprise into the theory of international trade," Journal of Economic Perspectives, Vol. 9: 169-189.

Noguer, M. and M. Siscart (2005), "Trade raises income: A precise and robust result," Journal of International Economics Vol. 65, No. 2: 447-60.

Roberts, M. and J. Tybout, eds. (1996), Industrial evolution in developing countries: Micro patterns of turnover, productivity and market structure, Oxford: Oxford University Press.

Schiff, M. and Y. Wang (2006), "North-South and South-South trade-related technology diffusion: An industry level analysis of direct and indirect effects," Canadian Journal of Economics, Vol. 39: 831-44.

Schiff, M. and Y. Wang (2008), "North-South and South-South trade-related technology diffusion: How important are they in improving TFP growth?" Journal of Development Studies, Vol. 44, No. 1: 49-59.

Seck, A. (2011), "International technology diffusion and economic growth: Explaining the spillover benefits to developing countries," Structural Change and Economic Dynamics, forthcoming.

The World Bank (2001), Trade blocs, Oxford: Oxford University Press.

Van Pottesberghe, B. and F. Lichtenberg (2001), "Does foreign direct investment transfer technology across borders?" Review of Economics and Statistics, Vol. 83, No. 3: 490-97.

Wang, Y. (2007), "Trade, human capital and technology spillovers: An industry level analysis," Review of International Economics, Vol. 15, No. 2: 269-283.

Wang, Y. (2010), "FDI and productivity growth: The role of inter-industry linkages," Canadian Journal of Economics, Vol. 43, No. 4: 1243-72.

Wong, W-K. (2004), "How good are trade and telephone call traffic in bridging income gaps and TFP gaps?" Journal of International Economics, Vol. 64: 441-63. 
